\title{
DEVELOPMENT A COMPUTER MODEL TO DETERMINE THE OPTIMUM LATERAL LENGTH OF MICROIRRIGATION SYSTEMS
}

\author{
Khedr $^{*}$ A. F., Rashad ${ }^{*}$ M. A., EIMasry* G. M., El-Sayed* A. S., and \\ Hegazi*** $^{* *}$ M.
}

\begin{abstract}
This study was carried out for developing a computer model to determine the optimum length of lateral in microirrigation systems. The model was designed to obtain a flow variation $\left(q_{\text {var }}\right)$ of 10, 15 and $20 \%$ and/or coefficient of uniformity (CU) greater than $85 \%$. The model was then validated by a hydraulic experiment which measure $C U$ of five emitters. The examined emitters were in-line $\left(E m_{3}\right)$, on-line $\left(E m_{1}, E m_{2} ; E m_{4}\right)$ and $\mathrm{Em}_{5}$ was microtube (a $3.80 \mathrm{~mm}$ inside diameter with a length of $50 \mathrm{~cm}$ ), at four lateral lengths, under seven operating pressures. The theoretical model and the validation experiment were compared indicating that there was a strong relationship with coefficient of determination $\left(R^{2}\right)$ more than 0.95 between the measured and predicted $C U$ for $E m_{1}, E m_{2}$ and $E m_{3}$, while this relationship was decreased with $R^{2}$ about 0.80 for $E_{4} m_{4}$ and $\mathrm{Em}_{5}$ at different treatments.
\end{abstract}

Keywords: Computer modeling, Lateral, Pressure, Uniformity, Microirrigation system.

\section{INTRODUCTION}

icroirrigation includes any localized irrigation method such as
trickle, spray and/or bubbler that slowly and frequently
provides water directly to the plant root zone. The slow rate of water application at discrete locations with certain operating pressure at only a portion of the soil volume in the field can result in a relatively low cost water delivery systems, with a higher uniformity coefficient, as well as reductions in water diversions compared to other irrigation methods (Lamm et al., 2007, ASABE Standard, 2008 and Ngigi, 2008). Microirrigation is a technique that enables us to save water and energy while economical, less laborious and more efficient irrigation can be achieved. The success of microirrigation is possible if the system is

\footnotetext{
"Assistant lecturer, Assistant Prof., Associate Prof. and Prof. of Agric. Eng., Agric. Eng. Dept., Fac. of Agric., Suez Canal Univ.

*** Prof. of Agric. Eng., Agric. Eng. Dept., Fac. of Agric., Ain Shams Univ.
} 
appropriately designed and managed. The first step in the design process of microirrigation system is to determine the optimum lateral lengths allow equal water distribution along the laterals. The characteristics of emitters and the friction losses along the lateral for a new produced microirrigation lateral are the main data for optimum lateral lengths (Yurdem et al., 2011).

Generally, the design of microirrigation systems is essentially depend on the assumption that the flow rates of emitters are the same along the laterals. Due to friction losses, some variations occur in flow rates. The selection of the appropriate flow rate, spacing and emitter types is the major role in designing an ideal microirrigation system. For instance, based on a desirable $90 \%$ of uniformity, Hanafy (1995) developed design charts that could be used in to selecting the optimum lateral lengths and diameter of the drip lateral line under the effect of total friction loss, emitter spacing and line slope. Generally, the pressure variation along the lateral line is determined by energy drop due to friction and energy gain or loss due to slope. The distribution uniformity substantially decreases at slopes steeper than $30 \%$ (Hassan, 2007). However, the successful design is usually a compromise between the choice of high uniformity and small cost of the installation.

There are significant differences in finding the frictional losses between the theoretical calculations using both the Darcy-Weisbach or HazenWilliams equations and the data obtained in the laboratory (Demir and Uz, 1995; Allen, 1996 and Demir, 1999). For this reason, researchers try to attain the data in the laboratory and to determine the friction losses (Pitts et al., 1986). In addition to these, some studies using dimensional analysis were carried out recently in order to develop some empirical models for predicting the friction losses (Demir et al., 2007 and Yildirim, 2010).

Because uniformity is an important parameter in the design and operation of microirrigation systems ( $\mathbf{L i}$ et al., 2012) several classification standards for microirrigation uniformity have been developed in different countries. Microirrigation uniformity classifications, ranging from excellent to unacceptable, were recognized by the American Society of Agricultural Engineers (ASAE Standard, 1999) for point source 
emitters. Uniformity below $60 \%$, from 60 to $70 \%, 70$ to from $80 \%$, from 80 to $90 \%$, and above $90 \%$ is referred to as low, poor, fair, good and excellent uniformity, respectively. Also, manufacturer's coefficient of variation $C_{v}$ is one of the significant factors affecting the overall uniformity of the microirrigation system. Classification $C_{v}$ is unacceptable (> 0.15$)$, poor (0.11 to 0.15$)$, marginal ( 0.07 to 0.11$)$, average (0.05 to $0.07)$, excellent $(<0.05)$ and these guidelines have been stated in Standards of American Society of Agricultural and Biological Engineering (ASABE Standards, 2003 and 2008).

Although there is already available software in the market for designing microirrigation systems, there is no software to define the optimum technical properties of new designed emitters and estimating the appropriate length of laterals. Hence, the main objective of this study was to develop a computer model to determine the optimum lateral length for different emitters, which improve the hydraulic performance of the subunit. The study also aimed to validate the results obtained from the model by verification in a laboratory hydraulic experiment.

\section{MATERIALS AND METHODS}

\section{Mathematical model}

In this study, a mathematical model depending on a set of algebraic equations of the microirrigation system was proposed and a program written in MATLAB version 10.0 (The Mathworks Inc., Natick, MA, USA) was developed for solving such equations to predict uniformity, discharge, number of emitters and optimum lateral length. The program was then tested and verified according to the data obtained from a laboratory experiment.

Under different operating pressure head $h_{i}(\mathrm{~m})$, the emitter flow rate $q$ $(\ell / \mathrm{hr})$ and the coefficient of variation $\left(C_{v}\right)$ of every emitter tested in this study could be obviously estimated according to the following two equations emphasized by ASABE Standards (2003 and 2008) and suggested by many researchers (Keller and Karmeli, 1974 and 1975; Wu and Gitlin, 1974):

$$
\begin{aligned}
& q=k h_{i}^{x} \\
& C_{v}=\frac{S}{\bar{X}}
\end{aligned}
$$


where, $k$ is a dimensionless constant of proportionality that characterizes each emitter, $x$ is a dimensionless emitter discharge exponent that is characterized by the flow regime and $\bar{X} ; S$ are the mean discharge and standard deviation of emitters.

In this study, the prediction of the friction losses between two microtube devices can also be made possible without testing friction losses in the laboratory by using the mathematical model. Thus, the Darcy-Weisbach and Blasius equation can be used to calculate the friction head loss for small diameter and smooth pipes (Keller and Bliesner, 1990, Demir, 1995 and El-Meseery, 1999) as:

$$
h_{f}=f \frac{L V^{2}}{d 2 g}
$$

where, $h_{f}$ is the friction loss in the pipe (m), $L$ is the pipe length (m), $d$ is the pipe's internal diameter $(\mathrm{m}), V$ is the velocity of the flow inside the emitter $(\mathrm{m} / \mathrm{s}), g$ is the acceleration of gravity $\left(9.81 \mathrm{~m} / \mathrm{s}^{2}\right)$, and $f$ is the friction coefficient calculated as:

For laminar flow $\quad f=64 / R e \quad \operatorname{Re} \leq 2000$

For turbulent flow $\quad f=0.3164 / R e^{0.25} \quad 4000 \leq \mathrm{Re} \leq 100000$

As, the Reynolds number $(R e)$ is controlled by the internal diameter of the flow cross-section $\mathrm{d}(\mathrm{m})$ and the kinematics viscosity of water $(v=1.004$ $\mathrm{x} 10^{-6} \mathrm{~m}^{2} / \mathrm{s}$ at $20^{\circ} \mathrm{C}$ ), it could be utilized to characterizes the flow regime and the discharge $Q\left(\mathrm{~m}^{3} / \mathrm{sec}\right)$ passing through it to estimate the velocity of the flow inside the emitter $V(\mathrm{~m} / \mathrm{s})$ as:

$$
\operatorname{Re}=\frac{V d}{v} \quad \text { with } \quad V=\frac{4 Q}{\pi d^{2}}
$$

Accordingly, the friction loss in the pipe $h_{f}(\mathrm{~m})$ can be calculated as follow for laminar and turbulent flow:

For laminar flow $\quad h_{f}=\frac{1.16 L_{i} Q}{D^{4}}$

For turbulent flow $\quad h_{f}=\frac{0.471 L_{i} Q^{1.75}}{D^{4.75}}$

Because the total head losses $h_{f n}\left(\Delta h_{\mathrm{n}}\right)$ at any delivery location on lateral line is the accumulation of losses occurred along the line, following steps were followed to calculate the total head losses: 


$$
\begin{aligned}
h_{f 1} & =\Delta h_{1} \\
h_{f 2} & =\Delta h_{1}+\Delta h_{2} \\
h_{f_{n}} & =\sum_{n=1}^{N} \Delta h_{n}
\end{aligned}
$$

On the other hand, the head losses between each two successive emitter could be calculated from the following equation that differs slightly from equation (7) and (8) (noticing that at first microtube $\mathrm{L}_{\mathrm{i}}=\mathrm{S}$ ).

For laminar flow $\quad h_{f_{n}}=1.16 S\left(Q_{n}\right) D^{-4}$

For turbulent flow $\quad h_{f_{n}}=0.471 S\left(Q_{n}\right)^{1.75} D^{-4.75}$

Where, $S$ is the distance between two successive emitter (m), and $Q_{n}$ is the lateral line discharge at any emitter location (just before delivery inlet) $(\ell / \mathrm{hr})$.

In addition, the lateral line discharge at the first delivery $(Q)$ equals the discharge of all delivery as follows:

$$
Q=q_{1}+q_{2}+q_{3}+\ldots \ldots \ldots \ldots q_{n}
$$

Assuming that for equal delivery discharge

$$
q_{1}=q_{2}=q_{3}=q_{4}=\ldots \ldots \ldots \ldots q_{n}
$$

Thus, the lateral discharge will decrease subsequently after every emitter by a value equal to microtube $\left(E m_{5}\right)$ discharge $(q)$ :

$$
\begin{aligned}
& Q_{1}=N q \\
& Q_{2}=N q-q=q(N-1) \\
& Q_{n}=N q-(n-1) q=q(N-n+1)
\end{aligned}
$$

From equations 7 to 13 the friction head losses between each two successive emitters can be deduce as:

For laminar flow $\quad h_{f_{n}}=1.16 S q D^{-4}(N-n+1)$

For turbulent flow $\quad h_{f_{n}}=0.471 S q^{1.75} D^{-4.75}(N-n+1)^{1.75}$

Considering two emitters (microtubes) at each single outlet leads to the following two equations for calculating the friction head losses $h_{f n}(\mathrm{~m})$ in both laminar and turbulent flows, respectively:

For laminar flow $h_{f_{n}}=S\left[1.16(2 q) D^{-4} \sum_{i=1}^{N}(N-n+1)+\delta_{s}\right]$ 
For turbulent flow $h_{f_{n}}=S\left[0.471(2 q)^{1.75} D^{-4.75} \sum_{i=1}^{N}(N-n+1)^{1.75}+\delta_{s}\right]$

where, $q$ is the discharge through emitter $(\ell / \mathrm{hr}), D$ is the internal diameter of lateral line (mm), $S$ is the distance between microtubes $(\mathrm{m}), \delta_{s}$ is the slope, $N$ is the total number of emitter and $n$ is the number of estimated emitters.

In case of the in-line devices $\left(E m_{3}\right)$, the friction loss between emitters is given by the following equation (Demir et al., 2007 and Yurdem et al., 2011):

$$
h_{f n}=5.885 \times 10^{-5} Q_{i}^{1.725} D^{-2.203} S^{0.742} d^{-3.074} l_{e}^{0.066}
$$

where, $h_{f n}$ is friction head loss (m), $Q_{i}$ is the flow rate in lateral section $\left(\mathrm{m}^{3} / \mathrm{s}\right), D$ is the pipe internal diameter $(\mathrm{m}), S$ is the emitter spacing $(\mathrm{m}), d$ is the emitter internal diameter $(\mathrm{m})$ and $l_{e}$ is the emitter length $(\mathrm{m})$.

The in-line friction loss model is valid for the following ranges; $0.2 \leq S \leq$ $1 \mathrm{~m}, 12.53 \leq D \leq 13.77 \mathrm{~mm}, 11.33 \leq d \leq 12.05 \mathrm{~mm}, 31.53 \leq l_{e} \leq 68.68$ $\mathrm{mm}$ and $3591 \leq R e \leq 23688$.

On the other hand, for on-line emitter devices the friction loss between two emitters are given by the following equation:

$$
h_{f_{n}}=8859.16 Q_{i}^{1.789} D^{-3.904} S^{0.635} A_{e}^{1.153}
$$

Where, $A_{e}$ is emitter devices barb protrusion area $\left(A_{e}=(\mathrm{x}+\mathrm{y}) \mathrm{x} \mathrm{z} / 2\right)\left(\mathrm{m}^{2}\right)$. The on-line friction loss model is valid for $0.2 \leq S \leq 1 \mathrm{~m}, 12.01 \leq D \leq$ $13.68 \mathrm{~mm}, 27.51 \leq A_{e} \leq 36.06 \mathrm{~mm}^{2}$ and $4047 \leq R e \leq 22215$.

Accordingly, the pressure effective head $\left(h_{\mathrm{n}}\right)$ at the emitter was calculated as:

$$
h_{n}=H_{I}-h_{f_{n}}
$$

Determinations of the optimum length of the microirrigation laterals is not a straightforward task due to the fact that the laterals are not only smooth pipes but also have multiple outlets depending upon the emitter device and spacing. Since emitters discharge water along the lateral line, the total flow rate decreases and the pressure changes in the lateral line with respect to the length as shown in Figure (1). For this reason, pressure and flow rate relations are considered in order to determine the optimum lateral lengths and water distribution uniformity from emitters along the lateral line. 


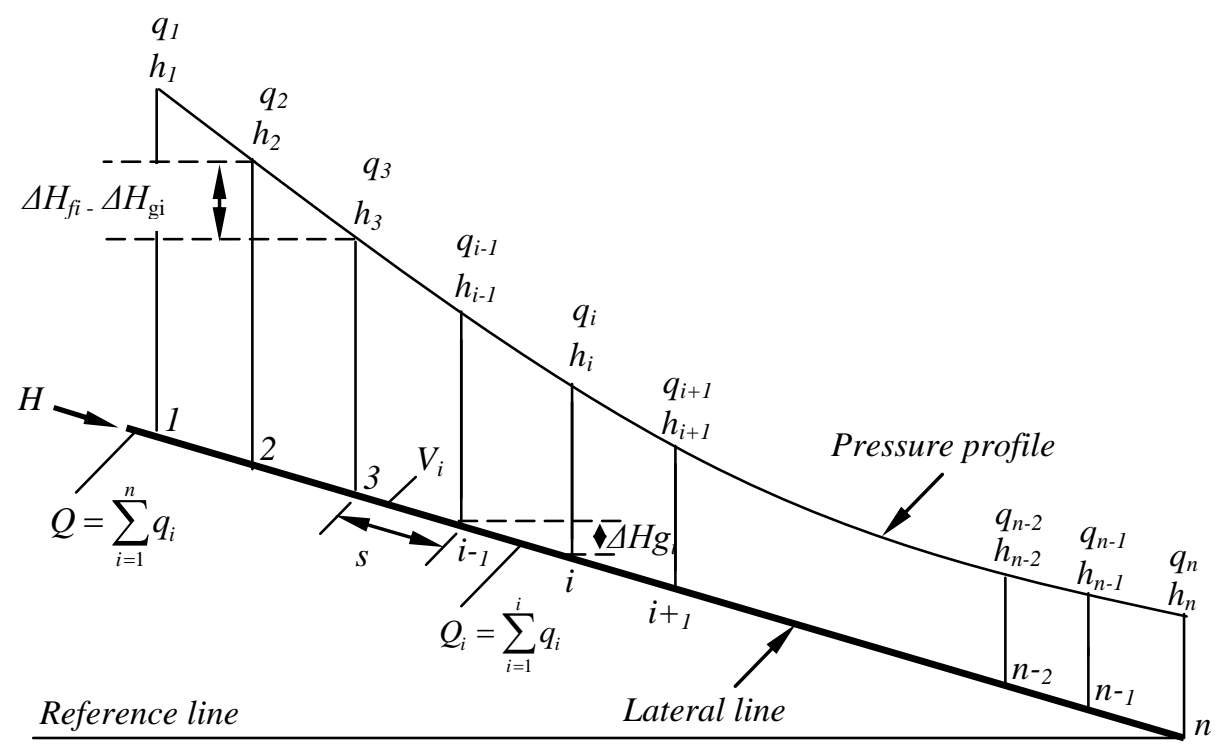

Figure (1): The pressure and flow rate distribution along the microirrigation lateral line (Yurdem et al., 2011).

As the emitter flow rates along the lateral for each emitter could be estimated by using equation (1), the inlet pressure $h_{i}$ in the abovementioned equation was calculated as:

$h_{i}=h_{i-1}-\Delta H_{f} \pm \Delta H_{g}$

where, $h_{i}$ is inlet pressure head at $i$ emitter (m), $h_{i-1}$ is inlet pressure head at $i-1$ emitter $(\mathrm{m}), \Delta H_{f}$ is the friction loss between emitter $i$ and emitter $i$ $l(\mathrm{~m})$, and $\Delta H_{g}$ is the elevation between emitter $i$ and emitter $i-l(\mathrm{~m})$.

Design criterias were computed simultaneously in a back-propagation manner in the developed program. Several criteria were used to calculate the optimum length of the laterals in order to obtain uniform water distribution and force the program to stop running. The coefficient of discharge uniformity $(C U)$ was a better way of expressing the hydraulic performance of the subunit. The uniformity of irrigation could be determined by Christiansen (1942).

$$
C U=100\left(1-\frac{\sum_{i=1}^{i=n}\left|q_{i}-\bar{q}\right|}{n \bar{q}}\right)
$$

where, $\sum_{i=1}^{i=n}\left|q_{i}-\bar{q}\right|$ is the summation of absolute values of deviations from means of emitter discharge, $q_{i}$ is individual of discharge of an 
emitter $(\ell / \mathrm{hr}), \bar{q}$ is the mean of discharge of an emitter $(\ell / \mathrm{hr})$ and $n$ is the number of estimated emitters. The optimum lateral length was then estimated based on the aforementioned equations in order to meet the limitations of $C U$ greater than $85 \%$.

Another criterion is the emitter flow variation $\left(q_{v a r}\right)$ and it is defined by (Jiang and Kang, 2010) equation as:

$$
q_{\mathrm{var}}=\frac{q_{\max }-q_{\min }}{q_{\max }} \times 100
$$

where, $q_{\max }$ and $q_{\min }$ are the maximum and minimum emitter discharge rate $(\ell / \mathrm{hr})$. Several researchers suggested a uniformity coefficient of trickle irrigation about $97.5 \%$ equivalent to $q_{v a r}$ of $10 \%$ and a uniformity coefficient of about $95.0 \%$ equivalent to $q_{v a r}$ of $20 \%$ (Bralts and Wu, 1979). The output data of the computer model (predicted values of uniformity, discharge, number of emitters and optimum lateral length) were then computed and computed with those obtained from the experimental works (the real measured values). The flowchart of the equations used in the model is given in Figure (2).

\section{Model validation}

Firstly, laboratory experiment was carried out to test the hydraulic characteristics of examined emitter devices. These characteristics were discharge exponent constants $x$ and coefficient of manufacturer's variation $C_{v}$. five types of emitters $(\mathrm{Em})$ purchased from the local market included two emitters from local manufacturers $\left(E m_{4}\right)$ were tested. The emitters were divided into manufactured in-line $\left(E m_{3}\right)$, on-line $\left(E m_{1}\right.$, $\left.E m_{2} ; E m_{4}\right)$ and microtube $E m_{5}(3.80 \mathrm{~mm} \mathrm{ID}$ with a length of $50 \mathrm{~cm})$ as shown in Figure (3, a, b; c) were tested under seven operating pressures from 20 to $120 \mathrm{kPa}$.

Secondly, validation of the model was carried out by comparing the measured with predicted coefficient of uniformity at different lengths of lateral $(15,20,25$ and $30 \mathrm{~cm}$ ) and different operating pressures (from 20 to $120 \mathrm{kPa}$ ) under Egyptian conditions with five emitter devices. Emitter discharges were calculated by dividing water volume in catch cans 


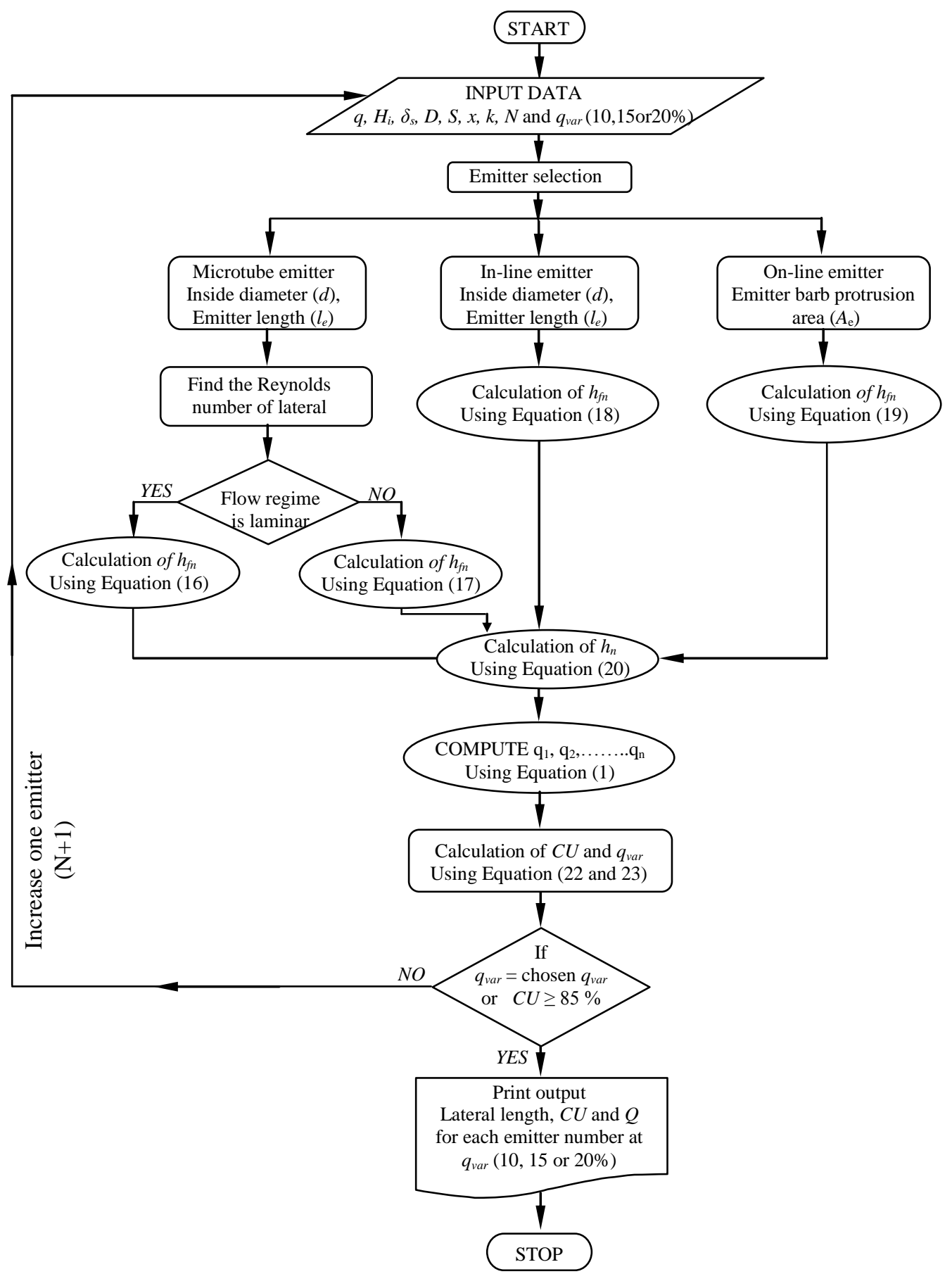

Figure (2): Schematic representations of the flowchart of the all involved steps and equations used in estimating the optimum length of microirrigation laterals. 
$180 \times 140 \mathrm{~mm}$ to collect the emitted water were placed along the lateral line directly below the emitters on a specified time under operating pressures. Drippers were selected on each emitter line at four locations (at the inlet, $1 / 3$ of the length, $2 / 3$ of the length and at the end of emitter line) as shown in Figure (4).

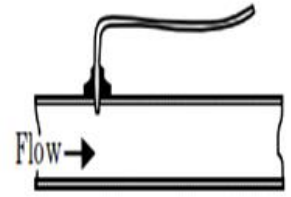

(a)

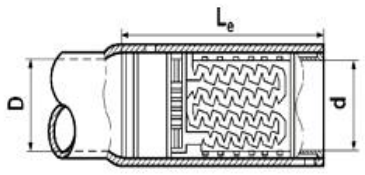

(b)

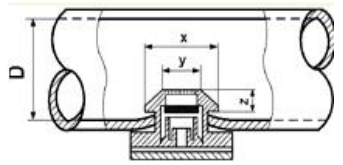

(c)

Figure (3): Schematic diagram of the tested emitter devices microtube, (b) in-line and (c) on-line emitters.

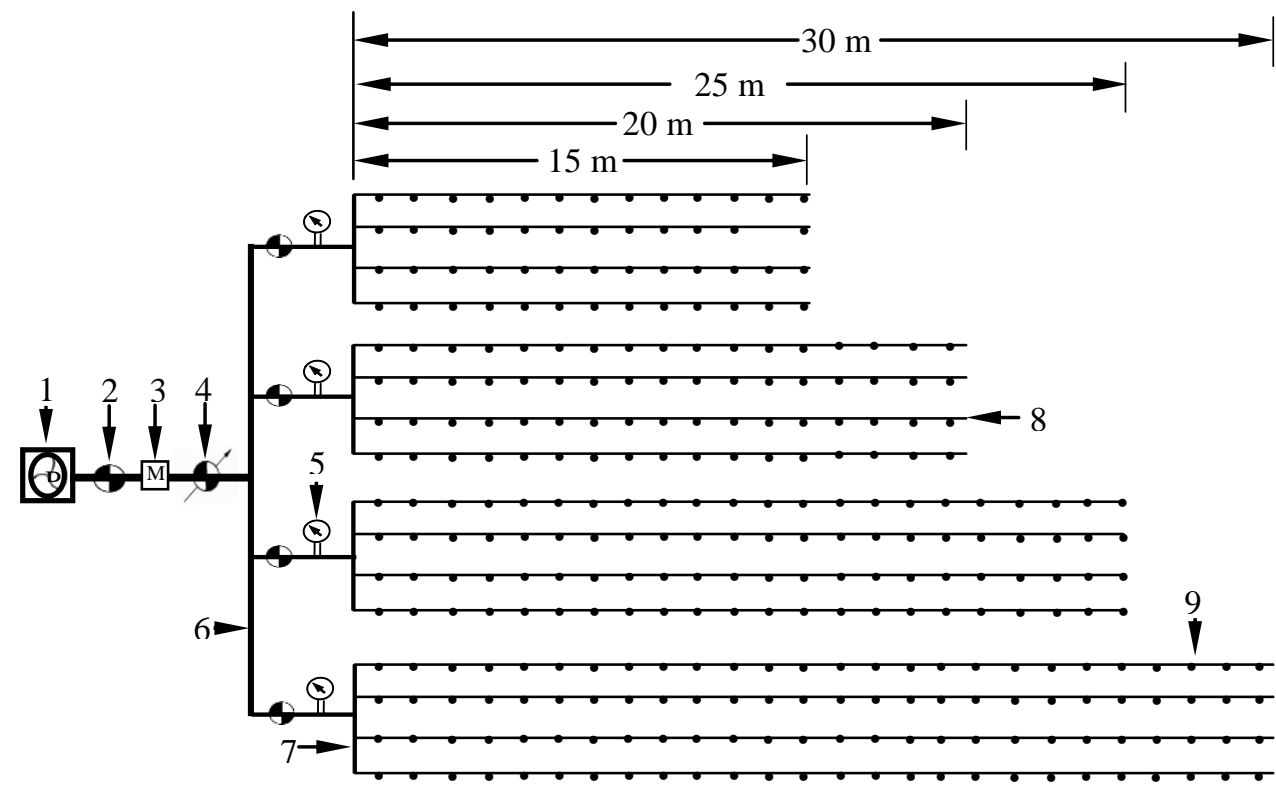

1- Pump 2- Valve 3- Water meter 4- Pressure regulator 5- Pressure gauge 6-Submain line 7-Manifold line 8- Lateral line 9-Emitter

Figure (4): Schematic diagram of the hydraulic subunits of different lateral lengths. 


\section{RESULTS AND DISCUSSION}

\section{Characterization of emitters}

As one of the key factors in selecting an emitter type and system design, the flow rate versus operating pressure relationship plays a vital role in the characterization of emitters in microirrigation systems. Table (1) shows the nominal and the measured flow rate, emitter discharge equation constants ( $k$ and $x$ ), flow regime, the manufacturer's coefficient of variation $C_{v}$ and the overall classification of the tested emitters. The data show that there were great differences between nominal and measured discharges for $E m_{4}$ emitter, which commonly handled types (un-published data about emitters by manufacturer). Also, the nominal flow rate of emitter $E m_{5}$ was unknown. Generally, the results indicated that the discharges of tested emitter types were highly affected by operating pressure.

Table (1): Average of flow rate $(\ell / h)$, emitter constants $(k, x)$, flow regime and manufacturing coefficient of variation $\left(C_{v}\right)$ for tested emitters at $100 \mathrm{kPa}$.

\begin{tabular}{|c|c|c|c|c|c|c|c|c|}
\hline \multirow[t]{2}{*}{$\begin{array}{c}\text { Emitter } \\
\text { (trademark) }\end{array}$} & \multicolumn{2}{|c|}{$\begin{array}{c}\text { discharge } \\
" \ell / h "\end{array}$} & \multirow[t]{2}{*}{$\begin{array}{c}\text { Difference } \\
\text { Percentage } \\
\text { "\%" }\end{array}$} & \multicolumn{2}{|c|}{$\begin{array}{c}\text { Emitter } \\
\text { constants }\end{array}$} & \multirow[t]{2}{*}{ Flow regime } & \multicolumn{2}{|c|}{$\begin{array}{c}\text { Coefficient of } \\
\text { variation } \\
" C v^{\prime \prime}\end{array}$} \\
\hline & Nominal & Measured & & "k" & $" x "$ & & Value & Class $* *$ \\
\hline $\begin{array}{l}\text { Eden } \\
\left(E m_{l}\right)\end{array}$ & 4.0 & 4.36 & 9.0 & 2.52 & 0.12 & $\begin{array}{c}\text { Pressure } \\
\text { compensating }\end{array}$ & 0.02 & Excellent \\
\hline $\begin{array}{l}\text { Euro-key } \\
\left(E m_{2}\right)\end{array}$ & 4.0 & 5.60 & 40.0 & 1.33 & 0.32 & $\begin{array}{c}\text { Partially } \\
\text { pressure } \\
\text { compensating }\end{array}$ & 0.02 & Excellent \\
\hline $\begin{array}{c}\mathrm{GR}^{*} \\
\left(E m_{3}\right)\end{array}$ & 4.0 & 3.95 & -1.25 & 0.61 & 0.38 & $\begin{array}{c}\text { Partially } \\
\text { turbulent }\end{array}$ & 0.03 & Excellent \\
\hline $\begin{array}{c}\text { Metallic } \\
\left(E m_{4}\right)\end{array}$ & 4.0 & 20.56 & 414.0 & 2.04 & 0.50 & $\begin{array}{c}\text { Fully } \\
\text { turbulent }\end{array}$ & 0.10 & Marginal \\
\hline $\begin{array}{c}\text { Microtube } \\
\left(E m_{5}\right)\end{array}$ & - & 102.0 & - & 7.82 & 0.63 & $\begin{array}{l}\text { Partially } \\
\text { turbulent }\end{array}$ & 0.23 & Unacceptable \\
\hline
\end{tabular}

"In-line emitter device. " Classification according to ASABE standards (2008).

The highest difference percentage of measured than nominal discharge was $414.0 \%$ for $E m_{4}$, while the lowest percentage $-1.25 \%$ was obtained with $E m_{3}$. The emitters' exponent $x$ showed that its classification lies between pressure compensating and turbulent. The measurements also indicated that the $E m_{1}, E m_{2}$ and $E m_{3}$ emitters were classified as excellent emitters based on $C_{v}$ values; meanwhile $E m_{4}$ was marginal and $E m_{5}$ was classified as unacceptable emitter. Due to the simple design of $E m_{4}$ 
emitter and their low $C_{v}$ they recorded high difference between nominal and measured discharge. Emitter $E m_{4}$ was just selected for the model validation experiment to represents the cheap and commonly used types in the local market.

\section{Mathematical model}

The developed programmed model in this study was used to determine uniformity, maximum discharge, ideal number of emitters, discharge of lateral, friction losses and the optimum length of lateral under different operating pressures and flow rate variations $q_{v a r}$ (i.e. 10, 15 and $20 \%$ ). The model was tested to estimate these parameters for different emitters as shown in Table (2). The results indicated that lateral length proportionally related with the operating pressures for all manufactured emitter, while it has no relationship with microtube $\left(E m_{5}\right)$. All emitters discharge had a proportional relationship with operating pressures. Although $C U$ values decreased by increasing the variations in flow rate $q_{v a r}, E m_{1}, E m_{2}, E m_{3}$ and $E m_{4}$ emitters still classified as excellent emitters under all operating pressures. While $C U$ value of the microtube $\left(E m_{5}\right)$ inversely proportional with discharge, its classification was decreased from excellent to good when the variations of flow rate $q_{v a r}$ increased from 10 to $20 \%$ at all operating pressures.

\section{Model validation}

The coefficient of uniformity $(C U)$ was determined at different levels of lateral length and operating pressure. The relationship between operating pressure and coefficient of uniformity for five emitters types at different lateral lengths is shown in Figure (5). It could be divided the emitters into two groups, the first group includes the manufactured emitters $E m_{1}, E m_{2}$, $E m_{3}$ and $E m_{4}$ emitters and the second group includes $E m_{5}$ as a microtube. Generally, for all manufactured emitters the $C U$ increased with increasing pressure until the maximum value with $100 \mathrm{kPa}$ and decreased again at all lateral lengths. Meanwhile, the $C U$ of microtube emitter $E m_{5}$ was decreased with increasing pressure at all lateral lengths. For all tested emitters, the reduction in $C U$ by increasing the lateral length could be attributed to the pressure losses (Amer, 2001, and Tagar, et al., 2010). 
Table (2): Prediction of optimum lateral length, total lateral discharge and coefficient of uniformity under different operating pressures and flow rate variations $\left(q_{v a r}: 10,15\right.$ and $\left.20 \%\right)$ for emitters.

\begin{tabular}{|c|c|c|c|c|c|c|c|c|c|c|}
\hline \multirow{4}{*}{$\begin{array}{l}\text { Emitter } \\
\text { type }\end{array}$} & \multirow{4}{*}{$\begin{array}{c}\mathrm{P} \\
(\mathrm{kPa})\end{array}$} & \multicolumn{9}{|c|}{ Optimum lateral length } \\
\hline & & \multirow{2}{*}{\multicolumn{3}{|c|}{$10 \%$}} & \multirow{2}{*}{\multicolumn{3}{|c|}{$\begin{array}{c}\text { Flow variation } \\
15 \%\end{array}$}} & & & \\
\hline & & & & & & & & \multicolumn{3}{|c|}{$20 \%$} \\
\hline & & $\begin{array}{l}L_{\max } \\
(m)\end{array}$ & $\underset{(\ell / h)}{Q}$ & $\begin{array}{l}C U \\
(\%)\end{array}$ & $\begin{array}{l}L_{\max } \\
(m)\end{array}$ & $\begin{array}{c}Q / h) \\
(\ell / h)\end{array}$ & $\begin{array}{l}C U \\
(\%)\end{array}$ & $\begin{array}{l}L_{\max } \\
(\mathrm{m})\end{array}$ & $\begin{array}{c}Q / h) \\
(\ell / h)\end{array}$ & $\begin{array}{l}C U \\
(\%)\end{array}$ \\
\hline \multirow{7}{*}{$E m_{1}$} & 20 & 19.8 & 248.2 & 98.37 & 28.8 & 361.0 & 97.05 & 35.4 & 443.7 & 95.75 \\
\hline & 40 & 33.0 & 448.8 & 98.36 & 50.1 & 681.4 & 97.09 & 61.2 & 832.3 & 95.76 \\
\hline & 50 & 35.1 & 494.9 & 98.58 & 57.0 & 803.7 & 97.24 & 71.4 & 1006.7 & 95.94 \\
\hline & 60 & 44.7 & 639.2 & 98.39 & 68.4 & 978.1 & 97.07 & 84.0 & 1201.2 & 95.79 \\
\hline & 80 & 74.7 & 1070.7 & 97.63 & 97.5 & 1397.5 & 96.36 & 112.2 & 1608.2 & 95.21 \\
\hline & 100 & 96.3 & 1399.6 & 97.33 & 120.6 & 1752.7 & 96.11 & 136.5 & 1983.8 & 94.99 \\
\hline & 120 & 116.1 & 1710.5 & 97.15 & 142.2 & 2095.1 & 95.11 & 159.3 & 2347.0 & 94.86 \\
\hline \multirow{7}{*}{$E m_{2}$} & 20 & 24.0 & 256.8 & 97.55 & 45.3 & 484.7 & 96.12 & 63.0 & 674.1 & 94.68 \\
\hline & 40 & 53.1 & 810.7 & 99.25 & 65.7 & 1003.0 & 98.38 & 78.6 & 1200.0 & 96.88 \\
\hline & 50 & 60.0 & 1070.0 & 98.18 & 66.0 & 1177.0 & 97.35 & 83.1 & 1482.0 & 95.33 \\
\hline & 60 & 63.0 & 1142.4 & 97.80 & 66.3 & 1202.2 & 96.57 & 85.2 & 1545.0 & 95.10 \\
\hline & 80 & 69.3 & 1279.7 & 96.61 & 77.1 & 1423.8 & 95.22 & 102.0 & 1883.6 & 93.82 \\
\hline & 100 & 86.7 & 1618.4 & 96.48 & 112.2 & 2094.4 & 95.10 & 134.7 & 2514.4 & 93.69 \\
\hline & 120 & 111.3 & 2125.8 & 95.62 & 135.9 & 2595.7 & 94.28 & 157.8 & 3014.0 & 92.89 \\
\hline \multirow{7}{*}{$\mathrm{Em}_{3}$} & 20 & 64.0 & 395.6 & 99.08 & 84.8 & 524.2 & 97.38 & 117.8 & 728.2 & 96.17 \\
\hline & 40 & 96.7 & 764.8 & 98.66 & 141.9 & 1122.3 & 97.24 & 201.0 & 1589.7 & 95.75 \\
\hline & 50 & 99.0 & 804.0 & 98.21 & 157.7 & 1280.7 & 97.81 & 210.9 & 1712.8 & 95.35 \\
\hline & 60 & 100.0 & 957.6 & 99.58 & 162.7 & 1558.0 & 98.16 & 217.8 & 2085.6 & 96.66 \\
\hline & 80 & 132.0 & 1416.0 & 99.68 & 173.9 & 1865.5 & 98.27 & 222.8 & 2390.0 & 96.76 \\
\hline & 100 & 133.0 & 1592.0 & 99.72 & 200.0 & 2393.9 & 98.35 & 260.7 & 3120.5 & 96.81 \\
\hline & 120 & 123.8 & 1523.1 & 99.27 & 196.7 & 2420.0 & 97.86 & 210.9 & 2594.7 & 96.35 \\
\hline \multirow{7}{*}{$\mathrm{Em}_{4}$} & 20 & 45.0 & 1407.0 & 98.00 & 57.9 & 1810.3 & 96.59 & 86.4 & 2701.4 & 95.16 \\
\hline & 40 & 52.5 & 2339.8 & 98.21 & 75.0 & 3342.5 & 96.79 & 92.4 & 4118.0 & 95.33 \\
\hline & 50 & 54.9 & 2796.2 & 98.76 & 69.9 & 3560.2 & 97.32 & 89.4 & 4553.4 & 95.86 \\
\hline & 60 & 72.9 & 3837.0 & 97.30 & 90.0 & 4737.0 & 95.91 & 105.0 & 5526.5 & 94.47 \\
\hline & 80 & 70.5 & 4368.7 & 97.78 & 87.9 & 5446.9 & 96.36 & 104.1 & 6450.7 & 94.94 \\
\hline & 100 & 77.4 & 5304.5 & 97.79 & 94.5 & 6476.4 & 96.70 & 108.9 & 7463.3 & 94.61 \\
\hline & 120 & 100.2 & 7004.0 & 95.75 & 113.1 & 7905.7 & 94.42 & 124.2 & 8681.6 & 93.08 \\
\hline \multirow{7}{*}{$E m_{5}$} & 20 & 16 & 1312.0 & 90.99 & 17 & 1394.0 & 88.52 & 19 & 1558.0 & 87.08 \\
\hline & 40 & 16 & 1984.0 & 90.15 & 17 & 2108.0 & 88.83 & 18 & 2232.0 & 87.37 \\
\hline & 50 & 15 & 2580.0 & 90.25 & 14 & 2408.0 & 88.75 & 15 & 2580.0 & 87.52 \\
\hline & 60 & 14 & 2464.0 & 90.11 & 15 & 2640.0 & 88.06 & 16 & 2816.0 & 87.32 \\
\hline & 80 & 15 & 2925.0 & 90.08 & 16 & 3120.0 & 88.29 & 17 & 3315.0 & 87.79 \\
\hline & 100 & 15 & 3060.0 & 88.71 & 16 & 3264.0 & 87.30 & 17 & 3468.0 & 86.14 \\
\hline & 120 & 15 & 3600.0 & 87.64 & 16 & 3840.0 & 86.03 & 17 & 4080.0 & 86.06 \\
\hline
\end{tabular}



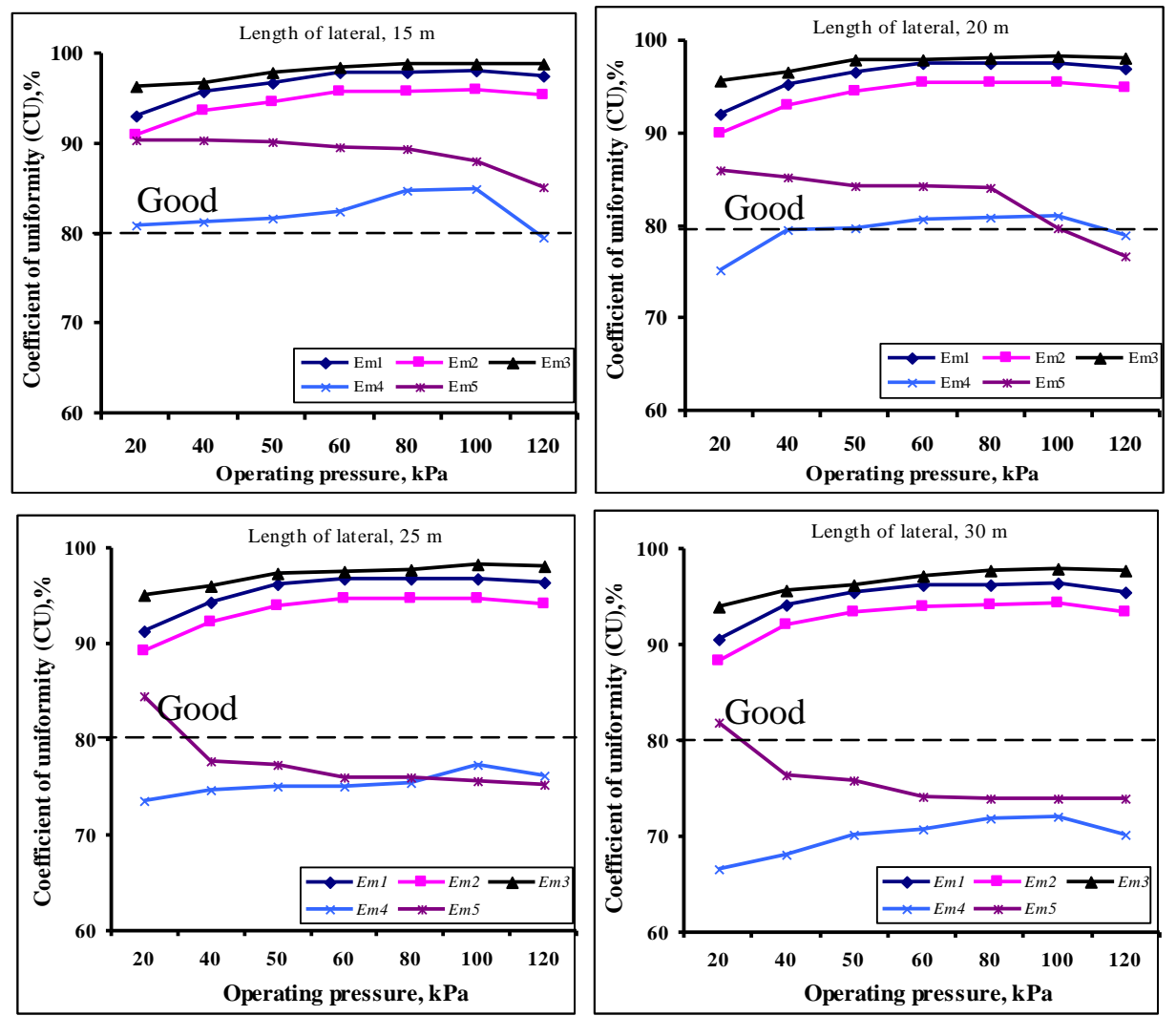

Figure (5): Relationship between operating pressure and coefficient of uniformity at different lateral length for different emitters.

The results indicate that the highest value of $C U$ was obtained at operating pressure of $100 \mathrm{kPa}$ and lateral length of $15 \mathrm{~m}$ for all tested ranges of operating pressures. The maximum values of $C U$ were 98.85, 98.01, 95.91 and $84.94 \%$ for the $E m_{3}, E m_{1}, E m_{2}$ and $E m_{4}$ emitters, respectively. The $C U$ values excellent classifications was achieved at lateral length of $30 \mathrm{~m}$ for $E m_{1}, E m_{2} ; E m_{3}$ emitters and lateral length of 15 $\mathrm{m}$ for $E m_{4} ; E m_{5}$ emitters were good as it was above $80 \%$. Emitter $E m_{4}$ represent an exception in which the increase in lateral length changed the $C U$ classification from good to poor according to ASABE standards (2008). However, the operating pressure of $20 \mathrm{kPa}$ and lateral length of $15 \mathrm{~m}$ for $E m_{5}$ as a microtube gave a $C U$ value of $90.43 \%$. Therefore, it can be concluded that the highest coefficient of uniformity could be achieved at operating pressure of $100 \mathrm{kPa}$ and length of lateral $15 \mathrm{~m}$ for the first group emitters and using $20 \mathrm{kPa}$ at the same lateral length for $E m_{5}$ microtube. 


\section{Model evaluation}

The equations solved by the developed model resulted in optimum values of microirrigation system design parameters (i.e. uniformity, maximum discharge of lateral, friction losses, ideal number of emitters and the optimum length of lateral). The model was then evaluated by comparing the values estimated by the model with those measured in the hydraulic experiment. The comparison between the measured and the predicted values is very important in order to check out how far the simulated results from the measured ones to evaluate the capability of the programmed model in analyzing new designed emitter devices. Coefficient of determination $\left(R^{2}\right)$ were approximately constant values about $0.96,0.95$ and 0.97 between measured and predicted $C U$ for different lateral lengths of emitters $E m_{1}, E m_{2}$ and $E m_{3}$, respectively as shown in Table (3).

There is an inverse relationship between the coefficient of determination and lateral length for $E m_{4}$ and $E m_{5} . R^{2}$ values were decreased from 0.88 to 0.80 and from 0.93 to 0.81 with $E m_{4}$ and $E m_{5}$, respectively at different lateral lengths from 15 to $30 \mathrm{~m}$. These differences between $R^{2}$ of local and imported emitters may be attributed to its $C_{v}$ values. The $C_{v}$ classification of $E m_{1}, E m_{2}$ and $E m_{3}$ were classified as excellent, while $C_{v}$ value of $E m_{4}$ and $E m_{5}$ was classified as marginal and unacceptable, respectively as shown in Table (1). The theoretical model and the validation experiment were compared indicating that there was a strong relationship between the measured and predicted $C U$ at different treatments.

Table (3): Coefficient of determination $\left(R^{2}\right)$ at different lateral lengths and emitters.

\begin{tabular}{|c|c|c|c|c|}
\hline \multirow{2}{*}{$\begin{array}{c}\text { Emitter } \\
\text { type }\end{array}$} & \multicolumn{4}{|c|}{ Coefficient of determination $\left(R^{2}\right)$} \\
\cline { 2 - 5 } & 15 & 20 & 25 & 30 \\
\hline & \multicolumn{4}{|c|}{ Length of lateral, $\mathrm{m}$} \\
\hline$E m_{1}$ & 0.9638 & 0.9603 & 0.9629 & 0.9559 \\
\hline$E m_{2}$ & 0.9539 & 0.9544 & 0.9525 & 0.9507 \\
\hline$E m_{3}$ & 0.9725 & 0.9717 & 0.9707 & 0.9634 \\
\hline$E m_{4}$ & 0.8845 & 0.8573 & 0.8136 & 0.8066 \\
\hline$E m_{5}$ & 0.9395 & 0.8644 & 0.8377 & 0.8169 \\
\hline
\end{tabular}

\section{CONCLUSION}

A computer model was developed by Matlab version 10.0 to determine optimum lateral length of microirrigation systems. The model was validated by hydraulic experiment for different emitters and lateral lengths $(15,20,25$ and $30 \mathrm{~m})$ under operating pressures (from 20 to 120 
$\mathrm{kPa})$. The emitters were divided into in-line $\left(E m_{3}\right)$, on-line $\left(E m_{1}, E m_{2}\right.$, $\left.E m_{4} ; E m_{4}\right)$ and microtube $\left(E m_{5}\right)$. The model was designed to obtain a $q_{v a r}$ of 10,15 and $20 \%$ and/or $C U$ greater than $85 \%$. $C U$ was inversely proportional with lateral length, the best results was obtained under 100 $\mathrm{kPa}$ for all manufactured emitters and $20 \mathrm{kPa}$ for microtube. The comparison between measured and predicted $C U$ at different lateral lengths and operating pressures for emitters, indicates a strong correlation with coefficient of determination $\left(R^{2}\right)$ more than 0.95 for $E m_{1}, E m_{2}$ and $E m_{3}$, while this relationship was decreased with $R^{2}$ about 0.80 for $E m_{4}$ and $E m_{5}$ at different treatments.

\section{REFERENCES}

Allen, R. G. (1996). Relating the Hazen-Williams and Darcy-Weisbach friction loss equations for pressurized irrigation systems. Applied Eng. in Agric. 12: 685 - 693.

Amer, K. H. (2001). Comparison between modern irrigation system designs. Ph.D. Thesis of Agricultural Engineering, Department of Agricultural Engineering, Faculty of Agriculture, Minufiya University, Egypt, PP: 156.

ASAE Standards (1999). EP 458: Field evaluation of microirrigation systems. St. Joseph, Michigan, ASAE, 918 - 924.

ASABE Standards (2003). EP 405.1 FEB03: Design and installation of microirrigation systems. St Joseph, Michigan, ASAE, 901 - 905.

ASABE Standard (2008). EP 405.1 APR1988: Design and installation of microirrigation Systems. ASAE, 1 - 5.

Bralts, V. F. and I. P. Wu (1979). Emitter flow variation and uniformity for drip irrigation. ASAE Paper No. 79 - 2099. p. 34 ASAE, St. Joseph, MI.

Christiansen, J. E. (1942). Irrigation by sprinkler. Bulletin 670 . California Agricultural Experiment Station. University of California. Berkeley, USA, PP: 124.

Demir, V.; H. Yurdem and A. Degirmencioglu (2007). Development of prediction models for friction losses in drip irrigation laterals equipped with integrated in-line and on-line emitters using dimensional analysis. Biosystems Engineering, 96(4): 617 - 631.

Demir, V. (1999). A research on the determination of the technical properties and frictional losses of the components used in microirrigation systems. Proceeding of the Seventh International Congress on Mechanization and Energy in Agriculture, A Dana, 
Turkey, PP: 84 - 89.

Demir, V. and E. Uz (1995). The comparison of friction loss equations employed in determining the optimum lateral lengths of drip irrigation systems. Proceedings of the $16^{\text {th }}$ National Agricultural Mechanization Congress, Bursa, Turkey, PP: 441 - 450.

El-Meseery, A. A. M. (1999). A study on design and evaluation of bubbler irrigation system, Ph.D. Thesis, Department of Agricultural Engineering, Faculty of Agriculture, Al-Azhar University, Egypt, PP: 125.

Hassan, N. S. H., (2007). Evaluation of trickle irrigation designs based on uniformity concept. M.SC. Dept. of Agric. Eng. Fac. of Agric., Ain Shams U., Egypt, PP: 119.

Hanafy, M. (1995). Trickle irrigation lateral design (II). Misr Journal of Agricultural Engineering, 12(1): 66 - 109.

Jiang, S. and Y. Kang (2010). Evaluation of micro-irrigation uniformity on laterals considering field slopes. Journal of irrigation and drainage engineering: 429 - 434.

Keller, J. and R. D. Bliesner (1990). Sprinkler and trickle irrigation. Van Nostrand, Reinhold, New York, PP: 652.

Keller, S. and P. Karmeli (1975). Trickle irrigation design. $1^{\text {st }}$. Ed., Rain Bird Sprinkler Manufacturing Corporation, Glendora, USA, PP: 133.

Keller, S. and P. Karmeli (1974). Trickle irrigation design parameters. Transaction of the ASAE, 17(4): 678 - 684.

Lamm, F. R.; J. E. Ayars and F. S. Nakayama (2007). Microirrigation for crop production: design, operation, and management. $13^{\text {th }}$ ed., Italy. Elsevier, 533-570.

Li, J.; W. Zhao; J. Yin; H. Zhang; Y. Li and J. Wen (2012). The effects of drip irrigation system uniformity on soil water and nitrogen distributions. Transactions of the ASABE (American Society of Agricultural and Biological Engineers, 55(2):415-427.

Ngigi, S. N. (2008). Technical evaluation and development of low-head drip irrigation systems in Kenya. Irrigation and Drainage. 57: 450 462.

Pitts, D. J.; J. A. Ferguson and R. E. Wright (1986). Trickle irrigation lateral line design by computer analysis. Transactions of the ASAE 29(5): 1320 - 1324.

Tagar, A. A.; M. S. Mirjat; A. Soomro and A. Sarki (2010). Hydraulic performance of different emitters under varying lateral lengths. Journal of Agricultural Engineering, Vet. Sci., 26(2): 48 - 59.

Wu, I. P. and H. M. Gitlin (1974). Drip irrigation design based on 
uniformity. Transactions of the ASAE 17(3): 429 - 432.

Yildirim, G. (2010). Total energy loss assessment for trickle lateral lines equipped with integrated in-line and on-line emitters. Irrig. Sci., (28): 341 - 352.

Yurdem, H.; V. Demir and A. Degirmencioglu (2011). Development of a software to determine the emitter characteristics and the optimum length of new designed drip irrigation laterals. Mathematical and Computational Applications, 16(3): 728 -737.

\section{الملخص العربى}

\section{تطوير نموذج حاسوب لتحديد أفضل طول خط جانبي لنظم الري الدقيق

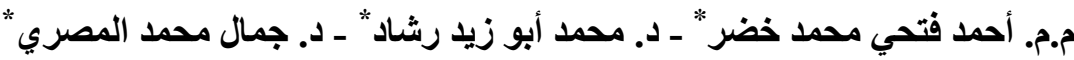

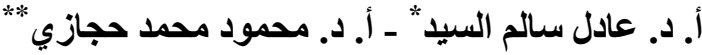

الهدف من هذه الدر اسة هو تطوير نموذج حاسوب يحدد أفضل طول مناسب لخط جانبي بنظم

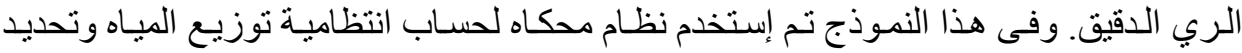

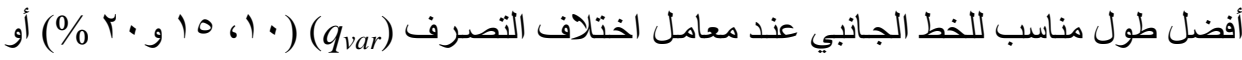
معامل انتظامية توزيع المياه (CU

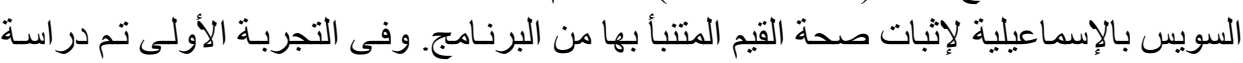

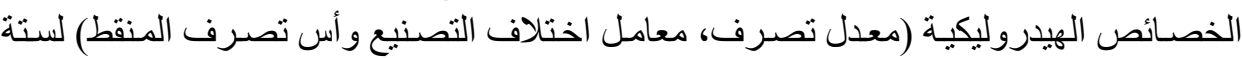

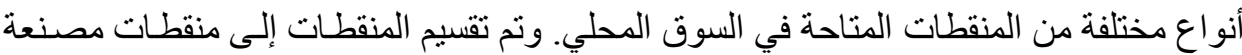
كوحدة واحدة مع الخط الجانبي (Em) الاداء Em

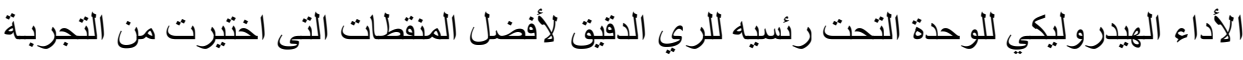

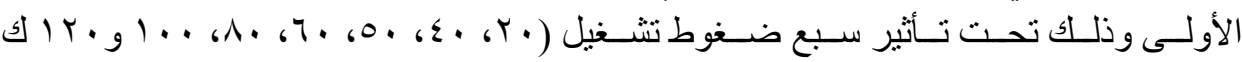

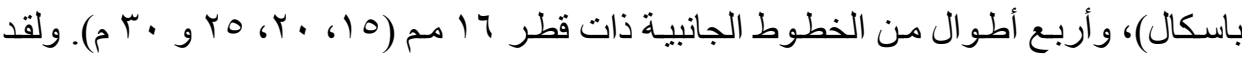

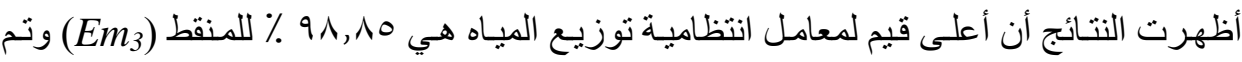

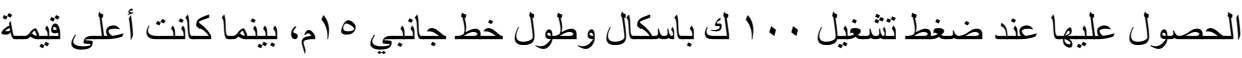

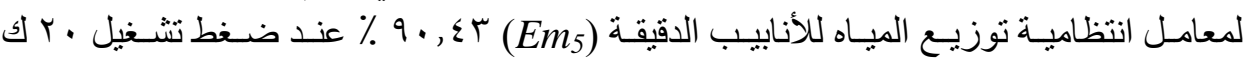

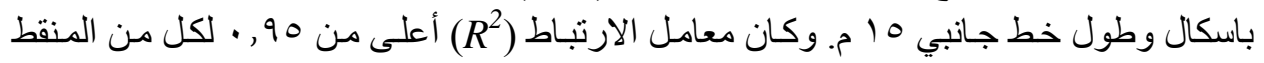

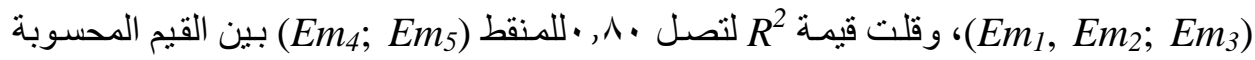
و القيمة المتنبأ بها لمعامل انتظامية توزيع المياه.

" مدرس مساعد، مدرس، أستاذ مساعد و أستاذ الهندسة الزراعية ـ قسم الهندسة الزراعية

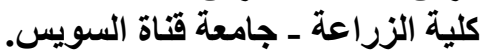
** (أستاذ الهندسة الزراعية ـ قسم الهندسة الزراعية ـ كلية الزراعة ـ جامعة عين شمس. 